\title{
弾性FEMによる軽量地盤材料を用いた壁体構造物 の土圧に与える境界条件の影響
}

\author{
村上 哲1 ·安原一哉 ${ }^{2} \cdot$ 小峯秀雄 $^{3} \cdot$ 佐藤匠 $^{4}$
}

\begin{abstract}
ジオシンセティックスの 1 つである軽量地盤材料の材料特性の 1 つに、従来の土質材料と比べポアソン比が 小さいことが挙げられる。軽量地盤材料が軽量であることとポアソン比が比較的小さい材料特性から、壁体構 造物の裏込め材料として軽量地盤材料を用いると壁面土圧が小さくなることが期待される。著者らは、この材 料特性に着目した数值解析の結果、ポアソン比が小さいとき土圧低減効果は期待されるが、境界の拘束条件に よって低減効果が変化することを明らかにした。本研究は、さらに裏込めの地山斜面と軽量地盤材料との境界 条件の違いによる壁面土圧の算定結果の比較を行うことにより, 軽量地盤材料の土圧低减効果について検討し たものである。
\end{abstract}

キーワード : 軽量地盤材料, 弾性体, 有限要素解析, 壁面土圧

\section{1.はじめに}

壁体構造物の裏込め材として, ジオシンセティックス の 1 つである軽量地盤材料を利用した場合, 一般の土質 材料よりも壁面土圧が小さくなることが知られている. 軽量地般材料に分類される気泡混合軽量土, 発泡ウレタ ン, E P Sの力学特性の共通的な特徵として, 一般の地 盤材料のポアソン比が $0.3 \sim 0.45$ と見積もられるのに対 し，気泡混合軽量土（石炭灰気泡混合軽量土）では 0.06 〜0.24 $4^{2}$, 発泡ウレタンでは $0.05^{3)}$, E P S では $0.06 〜$ $0.18^{4)}$ というように極めて小さなポアソン比を有すること に 1 つの特徴がある. 前報 1で゙は，切土斜面に軽量地盤 材料を利用した裏込め地盤を想定した有限要素弾性解析 を実施し、ポアソン比に着目した土压低減効果について 検討を行った。その結果、以下の知見を得た。

(1) 軽量地盤材料を想定したポアソン比 0.05 のケー スでは小さな壁面土圧となった。

(2) 壁面の高い位置ほど大きな土圧となった。斜面 を拘束条件で解いている影響と考えられる。

これらのことから, 斜面の拘束が土圧軽減効果に寄与し ている主要因であれば，斜面の接合が期待できるよう施 工管理を行う必要があること, さらに, 壁面土圧の軽減 効果について解明寸るためには，その他の要因について も検討することも重要となりうること, そして, 有限要
素解析結果は現地実験等の結果と比べて大きい值を示し たこと, など課題が挙げられ, 発泡ウレタンの材料特性 のみならず, その他の要因による土王低減効果のメカニ ズム解明を今後明らかにすべき点があることを指摘した。 そこで, 本研究は, 前報の解析条件において, 壁面およ び斜面の拘束条件を種々変えた数值計算を実施し、壁面 土圧に与える境界条件の影響について検討を行い、数值 解析上の留意事項について検討を行った。

\section{2. 壁面土圧弾性解析の概要}

軽量地盤材料の土圧低減効果について有限要素法を 用いた弾性解析 りにより検討するために, 図-1 で示した 道路盛士を想定した。 なお，裏込め斜面の勾配 $\theta$ は， $\theta$ $=30^{\circ} ， 45^{\circ} ， 60^{\circ}$ を想定する. また, 計算条件は裹込 めと地山斜面の境界は滑らないと考え固定とし，壁体と 裏込めの境界は摩擦が無い条件とした水平方向のみを固 定と滑らない条件とした鋁直および氷平方向を固定の 2 つを設定した. 境界条件を表-1 に示寸. 裏込めの材料 物性は発泡ウレタンを想定してヤング係数 $\mathrm{E}=4200 \mathrm{kN} / \mathrm{m}^{2}$, ポアソン比 $v=0.05$ を与えた.

上載荷重は単位分布荷重 $1 \mathrm{kN} / \mathrm{m}^{2}$ を与た。 単位分布 荷重を作用させたのは, 弾性解析であるので, 任意の大 きさの上載荷重を与えた場合は単位分布荷重に任意の大

\footnotetext{
1正会員, 茨城大学工学部 都市システム工学科, 助手（广316-8511 茨城県日立市中成沢町4-12-1）

2正会員, 茨城大学工学部 都市システム工学科, 教授（テ316-8511 茨城県日立市中成沢町4-12-1）

3非会員, 茨城大学工学部 都市システム工学科, 助教授（テ316-8511 茨城県日立市中成沢町4-12-1）

4非会員, 茨城大学工学部 都市システム工学科, 大学生（テ316-8511 茨城県日立市中成沢町4-12-1）
} 
きさだけ乗じればよいからである，なお，上載荷重に対 する土圧の低减効果を検討するために地盤材料の自重は 考慮しなかった。

この解析対象に有限要素法を用いた弾性解析を行う ための有限要素メッシュ図は図-2 である. 図は $45^{\circ}$ の ケースであり，節点数 76 個，要素数 55 個である．なお， その他のケースにおいても同様の節点数, 要素数で行っ ている. なお，解析と結果の整理においては圧縮方向を 正としている.

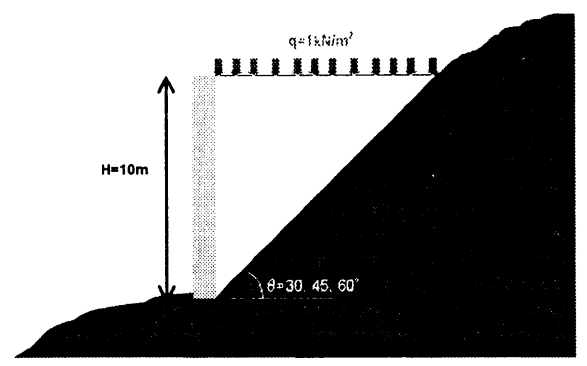

図-1 解析対象

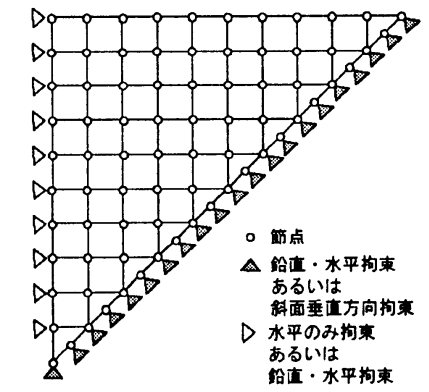

図-2 有限要素分割と境界条件

\begin{tabular}{|c|c|c|c|}
\hline \multicolumn{2}{|c|}{ 表- } & \multicolumn{2}{|c|}{ 境界条件の一覧 } \\
\hline $\begin{array}{l}\text { 計算 } \\
\text { ケ-ス }\end{array}$ & $\begin{array}{c}\text { 童远め } \\
\text { 斜面角度 } \theta\end{array}$ & $\begin{array}{c}\text { 壁面拘束の } \\
\text { 有無 }\end{array}$ & $\begin{array}{c}\text { 裳込め斜面拘束の } \\
\text { 有無 }\end{array}$ \\
\hline 1 & $30^{\circ}$ & 無 & 無 \\
\hline 2 & & 無 & 有 \\
\hline 3 & & 有 & 無 \\
\hline 4 & & 有 & 有 \\
\hline 5 & $45^{\circ}$ & 無 & 無 \\
\hline 6 & & 無 & 有 \\
\hline 7 & & 有 & 無 \\
\hline 8 & & 有 & 有 \\
\hline 9 & $60^{\circ}$ & 無 & 無 \\
\hline 10 & & 無 & 有 \\
\hline 11 & & 有 & 無 \\
\hline 12 & & 有 & 有 \\
\hline
\end{tabular}

\section{3. 軽量地盤材料の壁面土圧低減に関する解析的 検討}

解析結果を図-3〜5 に示す。いずれの図においても(a) 壁面土圧分布図は壁面に接触している要素の水平応力

（側方応力）を壁面に作用する土圧と考えて，それぞれ の境界条件での解析結果についてプロットしたものであ る. (b)斜面上の垂直応力の分布，および，(c)斜面上のせ ん断応力の分布もまた、斜面境界に接触しているようそ
の応力状態より斜面と同じ角度での要素内の垂直応力と せん断応力を算出してプロットしたものである。このと き垂直応力は圧縮方向を正，せん断応力は斜面上向きを 正としている。

図-3 5 の(a)図を見ると，いずれの裏込めの傾斜角度 においても斜面の拘束条件を非拘束とした計算結果で大 きな土圧分布を示している。また、壁面非拘束と斜面非 拘束の境界条件を除くと、壁面土圧の分布は上部で大き く，低い位置になるにつれ次第に減少していく傾向を示 している. 特に、斜面の拘束条件を拘束した場合は、比 較的小さな土圧分布を示した。これは，解析条件におい て裏込めと地山の境界を固定としたために裏込め材料の 変位に対して地山が拘束しているためによることが大き いと考えられる．なお、斜面およひ壁面を双方とも非拘 束とした解析ケースでは、斜面の角度に依らず、上載の 等分布荷重の圧力に等しい値となる。

壁体と裹込めの境界が拘束, 非拘束を比べると，壁 体高さ下部から中央部にかけてあまり違いは見られない が，上部付近では，拘束したケースでは大きな引張りの 力が作用していることが分る.したがって，壁体と裏込 めの境界が拘束しない場合より拘束する方が，壁体の剛 性を大きくする必要が生じると思われる.

斜面に作用寸る垂直応力は，図-3 5 の(b)図より，壁面 を拘束したケースでは，斜面角度 $30^{\circ}$ では斜面高さの 4 割程度まで，斜面角度 $45^{\circ}$ では 6 割程度まで，斜面角 度 $60^{\circ}$ では斜面高さの 7 割程度まで, 垂直応力の大き さは，斜面の拘束条件の大きな差異は見られないが，斜 面の上部においては，斜面非拘束の場合が大きな值とな った。これは，裏込め部分の下部においては，壁面の拘 束により斜面上の変位が抑制され，上部においては壁面 の拘束の影響範囲が小さくなったためである。

一方，斜面を拘束した結果において，壁面の拘束と非 拘束の違いを比較すると，斜面の下部において壁面を拘 束した場合より非拘束とした場合が大きな垂直応力が生 じている。これらの解析結果では, 壁面土圧の違いは比 較的小さかったが，壁面を非拘束とした場合，地山斜面 に作用寸る応力が大きることから，地山斜面の強度を十 分確保しておく必要があると思われる。

図-3 5 の(c)図における斜面に作用寸るせん断応力に おいて，斜面非拘束・壁面拘束のケースで若干正の值が 生じているのは, 有限要素分割の精度によるものであり, これらを無視すると，斜面を拘束しない場合は，せん断 応力が生じていない。図より，斜面を拘束したケースで は，斜面の上部ほど大きなせん断応力が生じていること が分かる。地盤内の水平応力分布を示した $(\mathrm{d}) \sim(\mathrm{g})$ を見 ると，斜面の境界条件を拘束した計算結果の方が拘束し ない計算結果に比べ、小さな水平応力分布を示している ことが分かる。この斜面を拘束条件とした場合、裏込め と地山の境界部上部での裏込め材料の要素は, やや引張 り状態にあることが分かる.これより，この効果が壁面 土压を小さくさせる要因の 1 つであると考えられる.

壁面および斜面の拘束条件を非拘束とした場合の解析 
結果を見ると、いずれの斜面角度においても一様な分布 を示している。これは両側面が滑らかであることから、 裏込めの変形が一様となったために起こったものである。 このために(a)図で示したように土圧分布は高さに依らず 一定值を示したことが分かる。

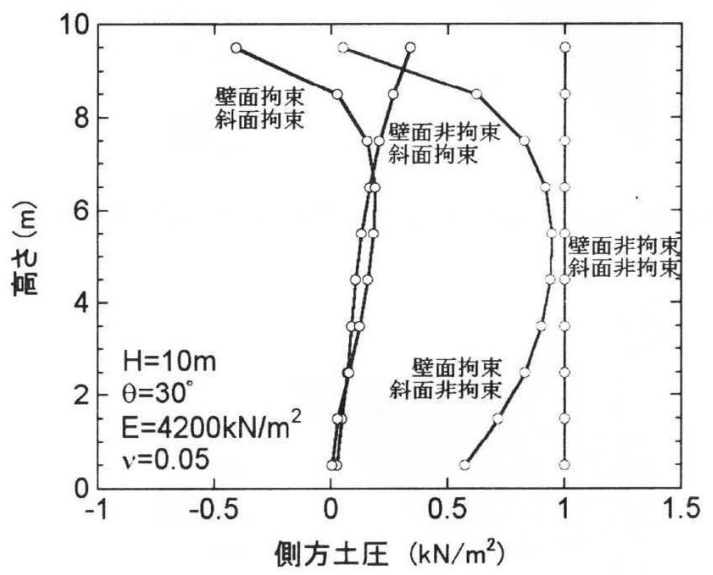

(a) 壁面土圧分布図 $\left(\theta=30^{\circ}\right.$ のケース $)$

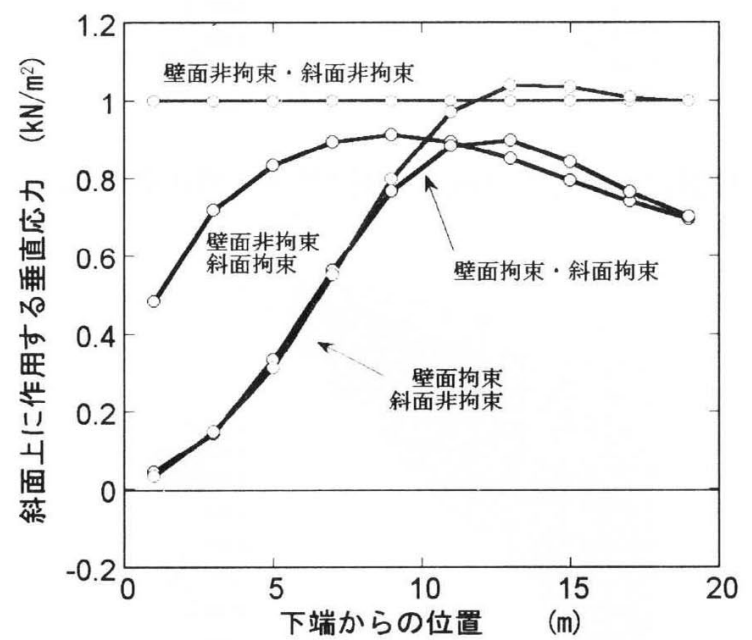

(b) 斜面上の垂直応力の分布

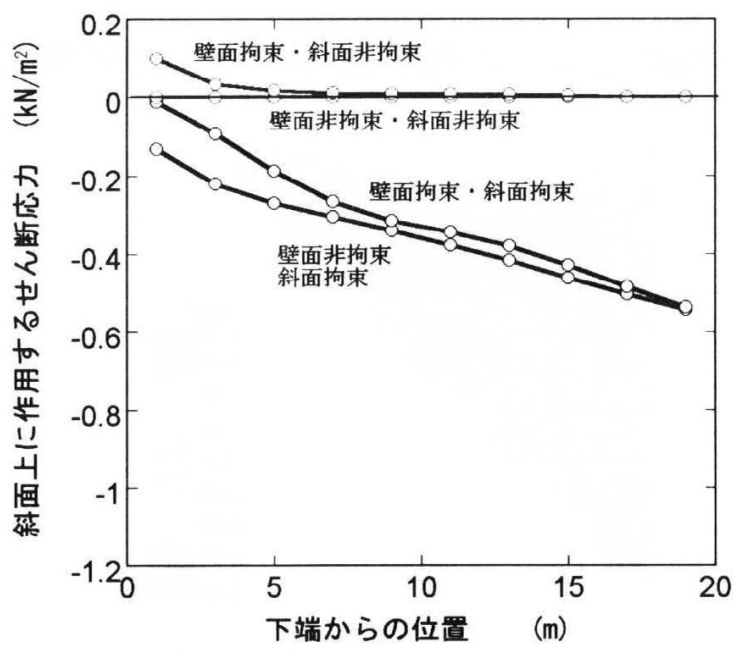

(c) 斜面上のせん断念力の分布
以上のように境界条件によって土圧分布が変化する ことが分かった。これらのことから、境界条件において は壁面の拘束よりも斜面の拘束が土圧低减に大きく寄与 することが分かる。すなわち、斜面と裏込めの境界を滑 らないように構築するほうが、壁面土圧低减効果が期待

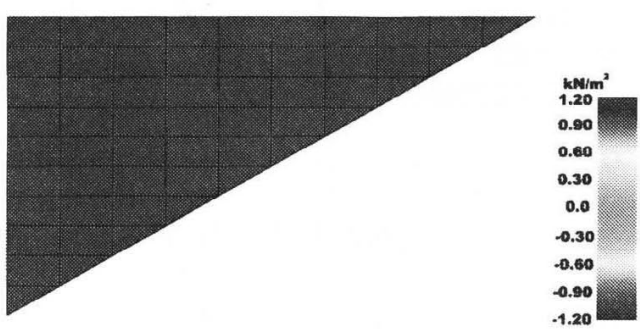

（d）地盤内水平応力分布図（壁面非拘束 - 斜面非拘束）

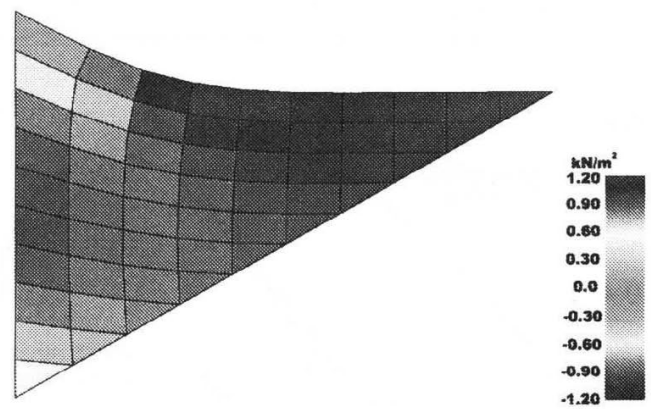

（e）地盤内水平応力分布図（壁面拘束 - 斜面非拘束）

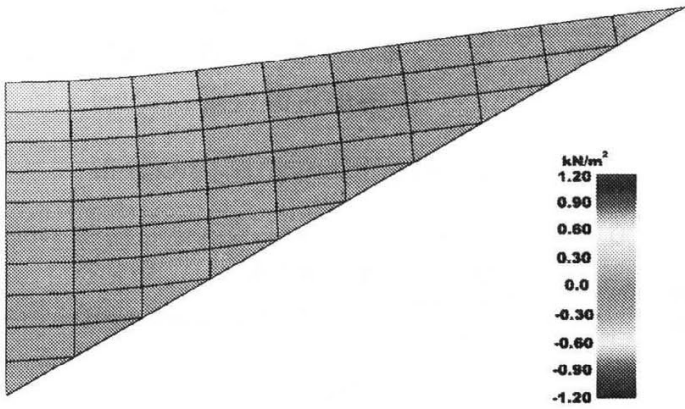

（f）地盤内水平応力分布図（壁面非拘束 - 斜面拘束）

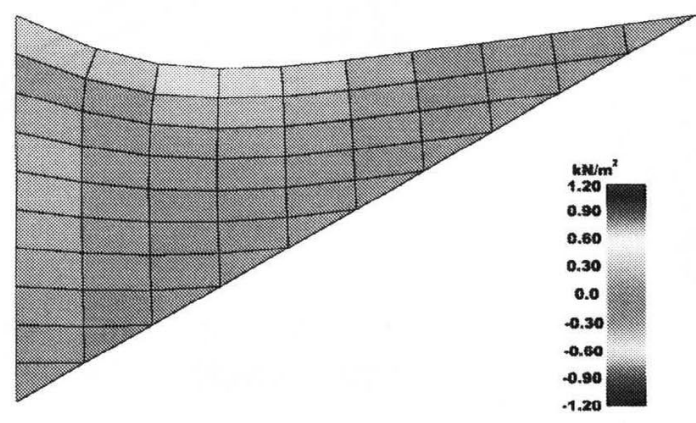

（g）地盤内水平応力分布図（壁面拘束・斜面拘束）

図-3 解析結果 $\left(\theta=30^{\circ}\right.$ のケース, 変位は $10^{3}$ 倍で表示 $)$ 


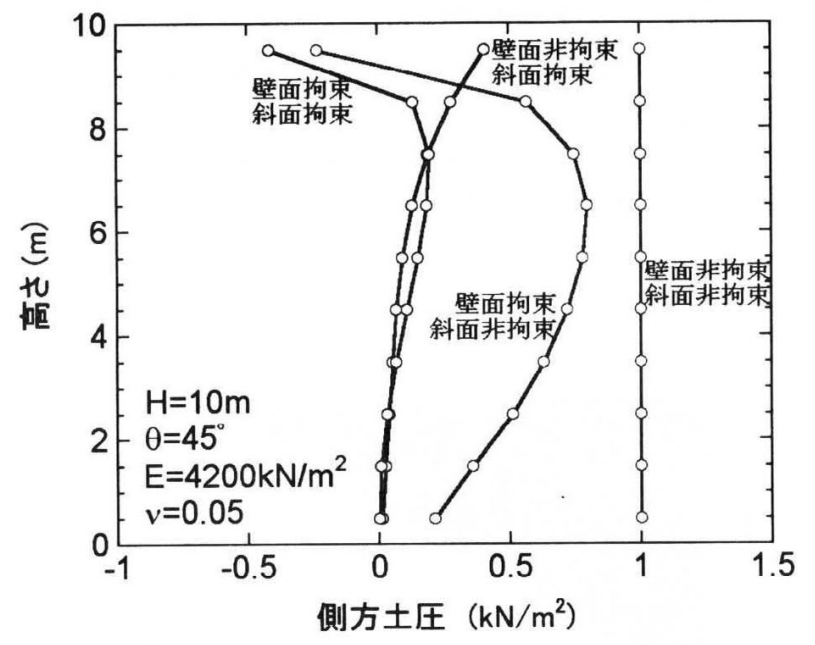

(a) 壁面土圧分布図

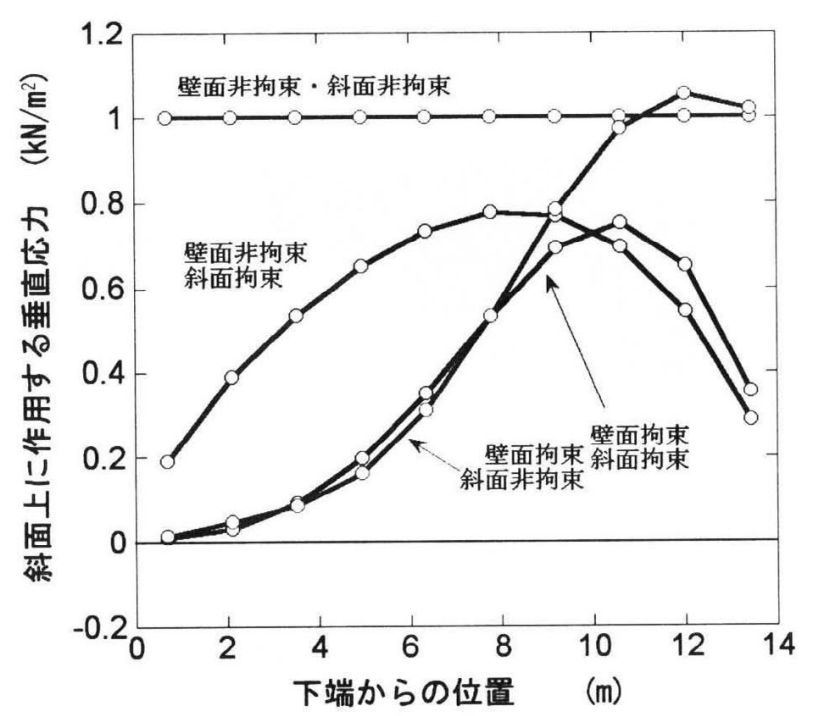

(b) 斜面上の垂直応力の分布

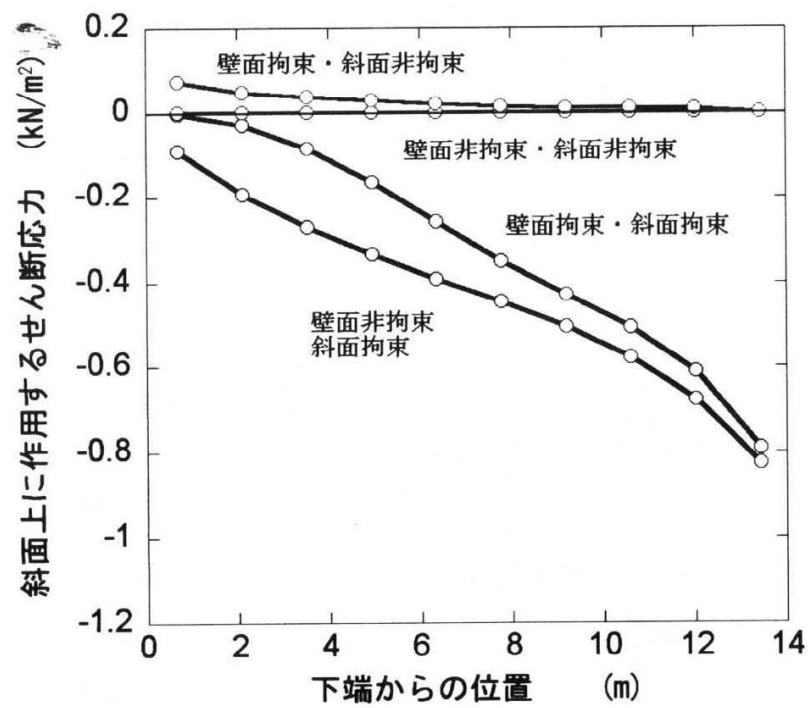

(c) 斜面上のせん断忘力の分布

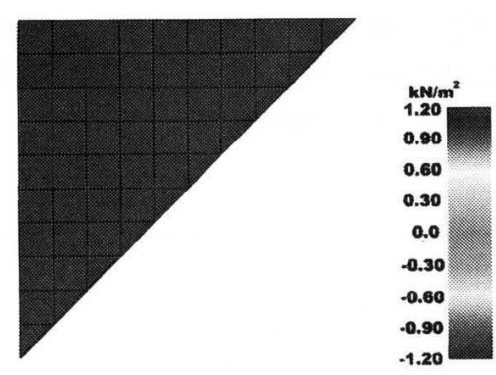

（d）地盤内水平応力分布図（壁面非拘束 - 斜面非拘束）

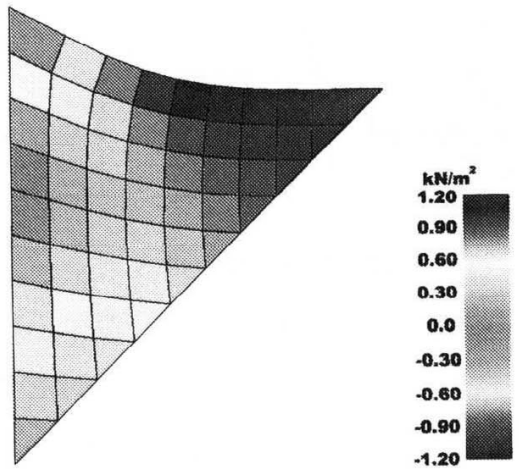

（e）地盤内水平応力分布図（壁面拘束・斜面非拘束）

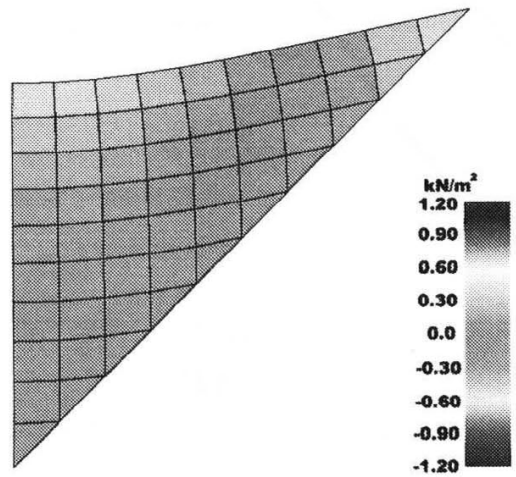

（f）地盤内水平応力分布図（壁面非拘束 - 斜面拘束）

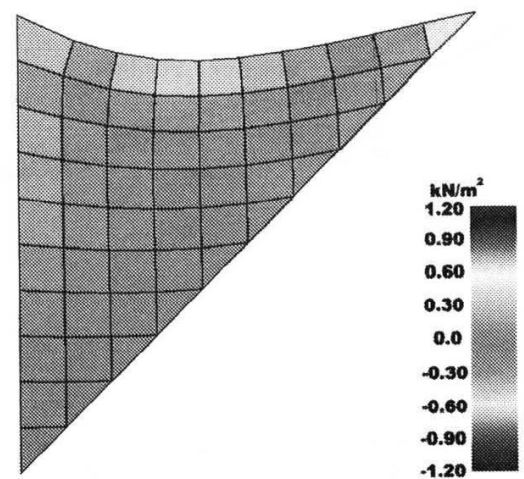

（g）地盤内水平応力分布図（壁面拘束 - 斜面拘束） 


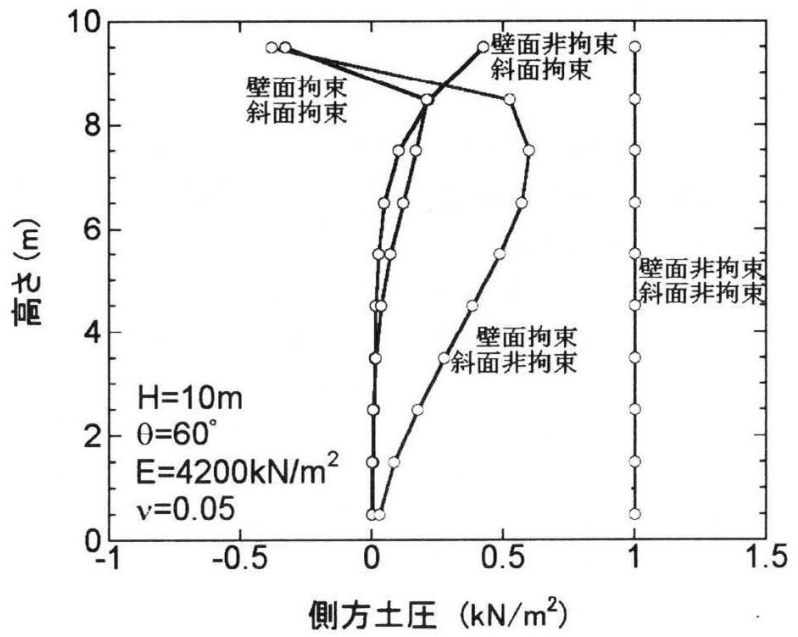

(a) 壁面土圧分布図 $\left(\theta=30^{\circ}\right.$ のケース $)$

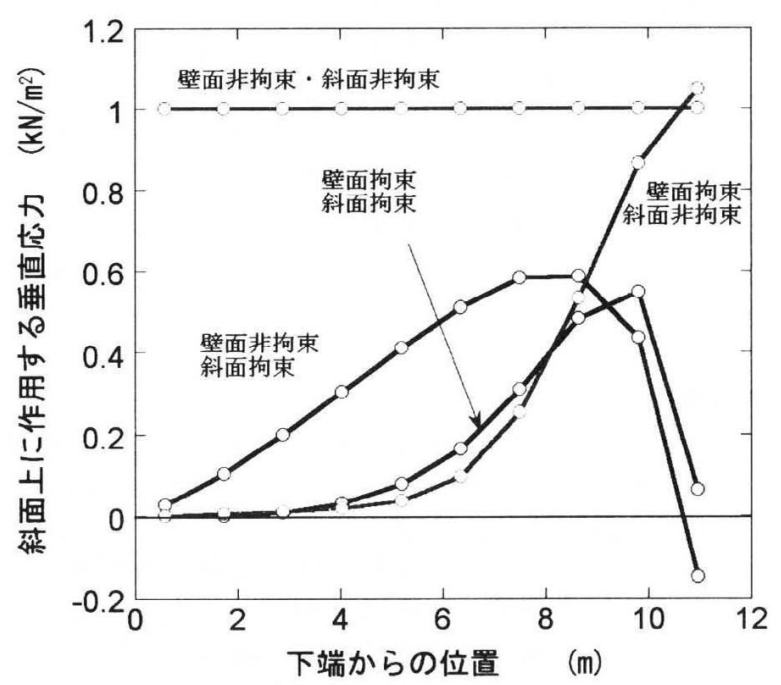

(b) 斜面上の垂直応力の分布

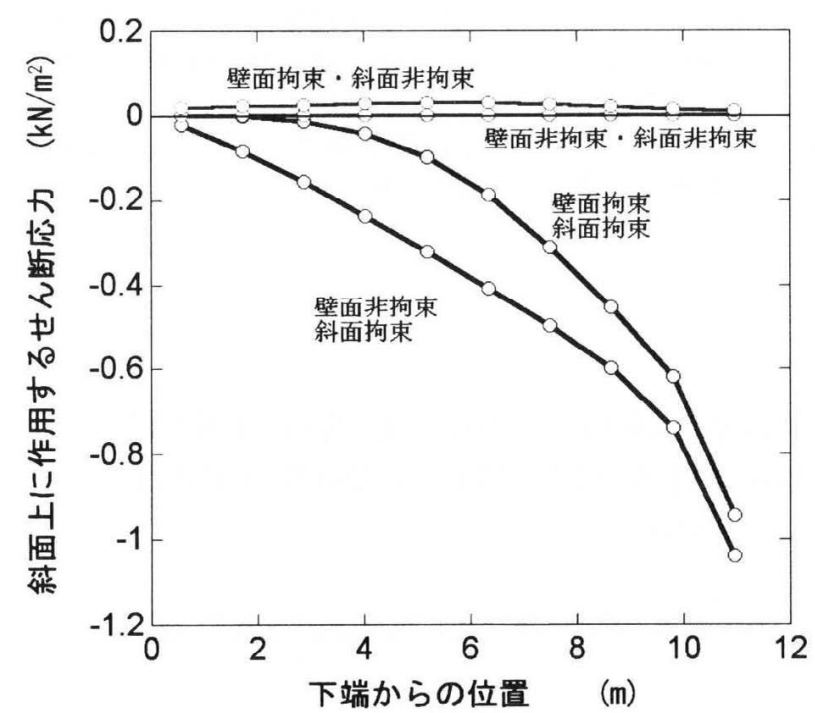

(c) 斜面上のせん断応力の分布

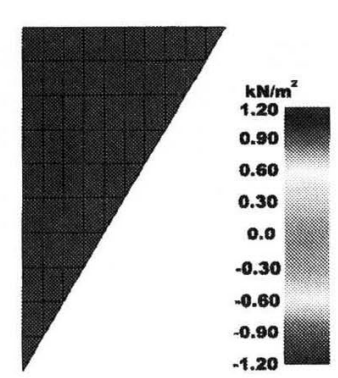

（d）地盤内水平応力分布図（壁面非拘束 - 斜面非拘束）

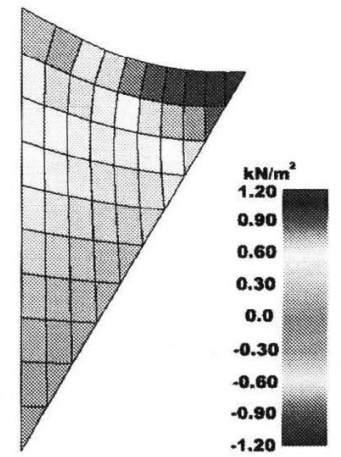

（e）地盤内水平応力分布図（壁面拘束 - 斜面非拘束）

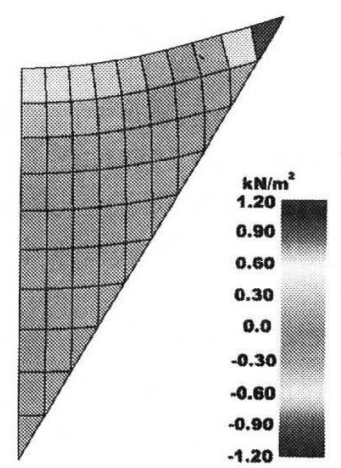

（f）地盤内水平応力分布図（壁面非拘束 - 斜面拘束）

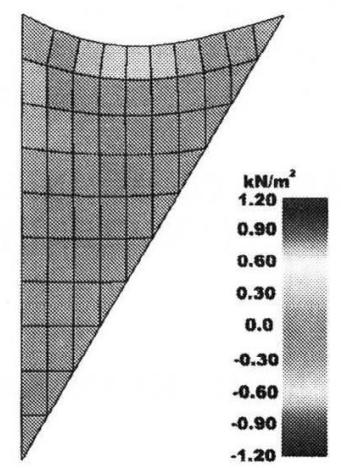

（g）地盤内水平応力分布図（壁面拘束 - 斜面拘束）

図-5 解析結果 $\left(\theta=60^{\circ}\right.$ のケース, 変位は $10^{3}$ 倍で表示 $)$ 
できると考える。一方，地山斜面に作用する応力に おいて垂直応力は壁面の拘束条件に影響を受けるこ とが分かる。

発泡ウレタン地盤は、およそ $10 \mathrm{~cm}$ 程度の間隔で

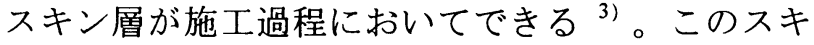
ン層は正常に発泡した部分よりも極めて剛な特性を 有し、比較的大きな伸縮を生じえない材料である。 また，EPS を利用する場合，EPS 間にコンクリート

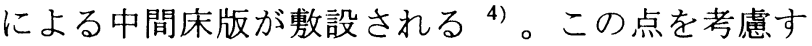
ると、軽量地盤材料が斜面上をすべるような変形モ 一ドを示した斜面を拘束しない解析条件ではなく、 斜面を拘束するような解析条件が実際の条件に近い と予想される。

\section{5. まとめ}

ジオシンセティックスの1つである軽量地盤材料 の壁面土圧軽減効果について有限要素法を用いた弾 性解析を行い, 壁面および斜面との境界条件に着目 した検討を行った。その結果, 以下の知見を得た。

（1）斜面の拘束条件を拘束した場合は、比較的小さ な土圧分布を示した。これは，解析条件におい て裏込めと地山の境界を固定としたために裹込 め材料の変位に対して地山が拘束しているため によることが大きいと考えられる。

（2）壁体と裹込めの境界が拘束，非拘束を比べると, 壁体高さ下部から中央部にかけてあまり違いは 見られないが，上部付近では，拘束したケース では大きな引張りの力が作用した。 したがって, 壁体と裹込めの境界が拘束しない場合より拘束 する方が，壁体の剛性を大きくする必要が生じ ると思われる.

（3）斜面に作用する垂直応力は，壁面を拘束したケ 一スでは, 斜面角度 $30^{\circ}$ では斜面高さの 4 割程 度まで, 斜面角度 $45^{\circ}$ では 6 割程度まで, 斜面 角度 $60^{\circ}$ では斜面高さの 7 割程度まで, 垂直応 力の大きさは, 斜面の拘束条件の大きな差異は 見られないが，斜面の上部においては，斜面非 拘束の場合が大きな值となった。これは，裏込 め部分の下部においては, 壁面の拘束により斜
面上の変位が抑制され，上部においては壁面の 拘束の影響範囲が小さくなったためである。

（4）一方，斜面を拘束した結果において，壁面の拘 束と非拘束の違いを比較すると，斜面の下部に おいて壁面を拘束した場合より非拘束とした場 合が大きな垂直応力が生じている。これらの解 析結果では, 壁面土圧の違いは比較的小さかっ たが，壁面を非拘束とした場合，地山斜面に作 用する応力が大きくなることから，地山斜面の 強度を十分確保しておく必要があると思われる。 以上のように壁面土圧に与える壁面および斜面の 境界条件の影響についての知見を得た。壁面土圧に ついては壁面の拘束よりも斜面の拘束が土圧低減に 大きく寄与することが分かった。一方，斜面土圧低 減には，壁面の拘束条件が寄与することがわかった。 なお、依然として現地観測結果においては今回の解 析結果より小さな土圧が観測された報告もあり、今 回解析において考慮されなかったコンクリート床版 やアンカーなど，発泡ウレタンと併用される材料に よる効果も含めたメカニズムの解明を行っていく必 要がある。また，軽量地盤材料には異方性を有する ことが知られている。この点についても今後検討を 重ねていきたい。

\section{参考文献}

1) 村上 哲, 安原一哉, 大信克男: 弾性FEMによる軽量 地盤の壁面土圧解析, ジオシンセティックス論文集 第17巻, pp.117-122, 2002.

2)安原一哉, 村上哲, 金澤浩明, 飯久保勉, 吉野博之, 堀内澄夫, 川野整: 石炭灰を利用した気泡軽量士の 強度 - 剛性と微視的要因の関係, 軽量地盤材料の開 発と適用に関するシンポジウム発表論文集, pp.149$154,2000$.

3) 財団法人土木研究センター: 現場発泡ウレタン軽量盛 土材料「フォームライトW」建設技術審査証明報告 書, p.139, 2001

4). 発泡スチロール土木工法開発機構：EPS工法設計・施 工基準書（案）, p.147，2002.

\title{
INFLUENCE OF BOUNDARY CONDITIONS ON EARTH PRESSURES OF LIGHT WEIGHT GEO-MATERIAL AGAINST RETAINING WALLS BY ELASTIC FINITE ELEMENT ANALYSIS
}

\author{
Satoshi MURAKAMI, Kazuya YASUHARA, Hideo KOMINE and Takumi SATOH
}

\begin{abstract}
One of the mechanical properties of such lightweight geo-materials in geosynthetics is that Poisson's ratio is very small, compared with natural geo-materials. In our previous study, the effect of the Poisson's ratio on earth pressure reduction are investigated, particularly in the case that the lightweight geo-material is applied as the back fill material of a retaining wall structure by using the elastic finite element analysis. Earth pressures against the retaining walls are reduced with decreasing the Poisson's ratio of the lightweight geo-material. In this study, the influence of boundary conditions between lightweight geo-material and retaining wall or natural ground on the earth pressure is investigated by using the elastic finite element analysis. It has been made clear that the earth pressure reduction effect in the case that boundary conditions of retaining wall and natural ground are fixed is the best in the calculated results.
\end{abstract}

